The INL is a

U.S. Department of Energy

National Laboratory

operated by

Battelle Energy Alliance

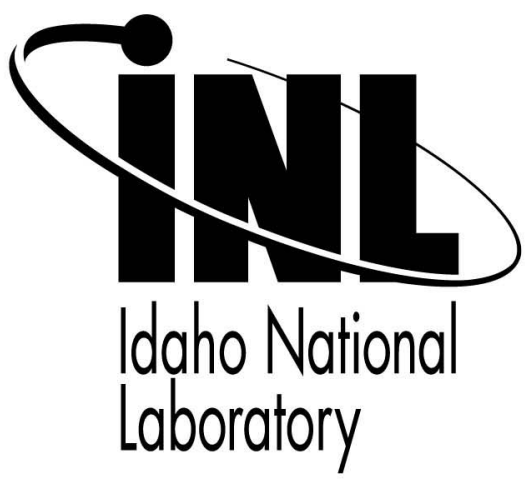

INL/CON-08-14673

PREPRINT

\title{
The Production of Syngas Via High Temperature Electrolysis and Biomass Gasification
}

\section{ASME International Mechanical Engineering Congress and Exposition}

\author{
M. G. McKellar \\ G. L. Hawkes \\ J. E. O'Brien
}

November 2008

This is a preprint of a paper intended for publication in a journal or proceedings. Since changes may be made before publication, this preprint should not be cited or reproduced without permission of the author. This document was prepared as an account of work sponsored by an agency of the United States Government. Neither the United States Government nor any agency thereof, or any of their employees, makes any warranty, expressed or implied, or assumes any legal liability or responsibility for any third party's use, or the results of such use, of any information, apparatus, product or process disclosed in this report, or represents that its use by such third party would not infringe privately owned rights. The views expressed in this paper are not necessarily those of the United States Government or the sponsoring agency. 


\title{
IMECE2008-68900
}

\section{THE PRODUCTION OF SYNGAS VIA HIGH TEMPERATURE ELECTROLYSIS AND BIOMASS GASIFICATION}

\author{
M. G. McKellar, G. L. Hawkes, J. E. O’Brien \\ Idaho National Laboratory \\ Idaho Falls, ID 83415, USA
}

\begin{abstract}
A process model of syngas production using high temperature electrolysis and biomass gasification is presented. Process heat from the biomass gasifier is used to improve the hydrogen production efficiency of the steam electrolysis process. Hydrogen from electrolysis allows a high utilization of the biomass carbon for syngas production. Based on the gasifier temperature, $94 \%$ to $95 \%$ of the carbon in the biomass becomes carbon monoxide in the syngas (carbon dioxide and hydrogen). Assuming the thermal efficiency of the power cycle for electricity generation is $50 \%$, (as expected from GEN IV nuclear reactors), the syngas production efficiency ranges from $70 \%$ to $73 \%$ as the gasifier temperature decreases from $1900 \mathrm{~K}$ to $1500 \mathrm{~K}$.
\end{abstract}

\section{NOMENCLATURE}

$\begin{array}{ll}\eta_{\text {syngas }} & \text { Syngas production efficiency } \\ \eta_{\text {th }} & \text { Thermal efficiency of power cycle } \\ \text { LHV } & \text { Molar lower heating value } \\ \dot{\mathrm{n}} & \text { Molar flow rate } \\ \text { Pwr } & \text { Power } \\ \text { elec } & \text { Electricity }\end{array}$

\section{INTRODUCTION}

The increase of oil prices, the need to reduce the dependence on foreign oil, and the concern for carbon emissions from fossil fuels has created an increased interest in the development of synthetic fuel sources. To reduce carbon dioxide emissions from fossil fuels, biomass to liquid fuel processes such as biodiesel and ethanol have been developed. These processes have an appeal in the sense that the carbon is recycled. However, many issues need to be addressed before the processes become economical. Such issues include biomass collection and preprocessing, maximizing carbon utilization, and process development and optimization.

Typical biomass gasification processes use smaller gasifiers compared to coal gasification due to gathering and transportation costs and issues [1]. Smaller sized units therefore have difficulty justifying the capital cost of air separation units. Therefore these units typically use air as the oxygen source for gasification.

To create a synthetic fuel, the biomass typically needs a hydrogen source. Hydrogen may come by adding steam directly to the gasification process or by steam reforming of natural gas. Direct steam injection has the advantage of adding a source of oxygen to the gasification process. However, additional heat is needed to create the steam. Steam reforming of natural gas also requires heat addition via the combustion of some of the natural gas [2]. The efficiency of producing hydrogen from the methane is about $70 \%$ [3].

Many forms of biomass have ash components (inorganic solids) that are very corrosive such as sodium, potassium, and phosphorus which set gasification temperatures below the slagging or melting temperatures of the ash. At these lower temperatures, chemical equilibrium is not achieved and the chemical kinetics of the process becomes important.

The Idaho National Laboratory is presenting with this paper, a process named Bio-Syntrolysis. This process converts biomass such as barley and wheat straw, corn stover, and wood chips into liquid synthetic fuel to be used in the transportation sector. Unique to this process is the coupling of the biomass gasification heat to the heating of the steam to be used in high temperature steam electrolysis (HTSE). The biomass provides the heat source and the carbon source for synthetic gas production. This process is different from typical biomass to liquid (BTL) gasification processes in that it creates hydrogen from HTSE with an input of electrical power. The source of this electrical power needs to be from a non fossil source such as nuclear, hydro, wind or solar in order to keep this process 
carbon-neutral. Presented in this paper is a process model flow sheet where syngas is produced. Processing of the syngas to liquid fuels is not modeled in this paper, but is considered in future modeling efforts of the authors.

\section{PROCESS DESCRIPTION}

The process model was developed using the Honeywell UniSim process modeling software. This commercial software is used in the oil and gas industry and can model thermochemical systems ensuring chemical, energy and mass balances [4].

The biomass for this analysis contains $4.9 \%$ ash, $11.5 \%$ water, and $83.6 \%$ barley straw by weight. The ultimate analysis of the dry, ash free, barley straw is shown in Table 1 and is based on the PHYLLIS database of the Energy Research Centre of the Netherlands [5]. The lower heating value of the barely straw is $18,460 \mathrm{~kJ} / \mathrm{kg}$. The dry ash is primarily silicon oxide with some potassium and calcium oxide. Both the ash and the dry, ash free, barley straw were modeled as hypothetical components. The composition and heating value of the barley straw are the only necessary components for the gasification process model. The gasifier uses a Gibbs reactor which minimizes the Gibbs free energy to determine the most likely products based on the composition, flow rates, pressure and temperatures of the barley straw, water, and oxygen. A large number of components were considered as products, but only those presented in Table 2 were present.

\section{Table 1. Ultimate Analysis of Barley Straw}

\begin{tabular}{|l|l|}
\hline \multicolumn{2}{|c|}{ Ultimate Analysis (wt. \%) } \\
Carbon & 49.19 \\
\hline Hydrogen & 5.80 \\
\hline Oxygen & 44.09 \\
\hline $\begin{array}{l}\text { Nitrogen } \\
\text { Sulfur }\end{array}$ & 0.43 \\
\hline Chlorine & 0.06 \\
\hline
\end{tabular}

Table 2. Molar Composition Exiting Gasifier

\begin{tabular}{|l|r|}
\multicolumn{1}{|c|}{ Component } & \% Mole Fraction \\
Carbon Monoxide & $51.81 \%$ \\
\hline Hydrogen & $43.86 \%$ \\
\hline Water & $2.22 \%$ \\
\hline Carbon Dioxide & $0.99 \%$ \\
\hline Nitrogen & $0.20 \%$ \\
\hline Hydrogen Chloride & $0.16 \%$ \\
\hline $\begin{array}{l}\text { Methane } \\
\text { Hydrogen Sulfide }\end{array}$ & $0.73 \%$ \\
\hline $\begin{array}{l}\text { Ammonia } \\
\text { Carbonoxysulfide }\end{array}$ & $242 \mathrm{ppm}$ \\
\hline
\end{tabular}

The primary purpose of modeling the ash is to simulate the heat captured by the ash during gasification, but the ash does not react chemically in the gasifier. A temperature dependent specific heat is determined based on the composition of the ash.

Figure 1 is the process flow diagram for biomass syngas production using high temperature electrolysis (HTE). The process is scaled to a biomass feed rate of $1 \mathrm{~kg} / \mathrm{s}$. The biomass is reacted with oxygen from the steam electrolyzer at a variety of gasifier temperatures ranging from $1500 \mathrm{~K}$ to $1900 \mathrm{~K}$. The gasification temperatures were selected to ensure chemical equilibrium and are based on temperatures for a Shell gasifier for coal [6]. Slagging of the ash will occur at those temperatures. Just enough oxygen is added to make the gasification process adiabatic.

The gasifier product stream and the hydrogen stream from the electrolyzer exit are cooled in the Heat Recuperator 1 heat exchanger to generate steam at $1073 \mathrm{~K}$ for the electrolysis unit. The water entering Heat Recuperator 1 is supplied by a makeup water source that is pumped to pressure and the water recycled from the electrolyzer outlet.

The gasifier product stream is quenched with water to the point of saturation for the purpose of modeling the energy loss due to particulate removal using a quenching process. The water contains some undesirable components from the gasifier including hydrogen sulfide and hydrogen chloride and therefore can not be recycled. The contaminants in this stream are removed in a contaminant removal process that is based on the Rectisol process. Methanol is refrigerated to $233 \mathrm{~K}$ and enters the top of an absorber. The gasifier product stream is cooled to remove excess water and enters the bottom of the absorber. The refrigerated methanol captures the hydrogen sulfide, some of the carbon dioxide, the ammonia, and the hydrogen chloride. The methanol is regenerated in a distillation column which is then recycled back to the absorber. Any losses of methanol are replaced. The contaminants exit the distillation column at the top of the column as a sour gas. The heat for the reboiler of the distillation column is provided by combusting some of the biomass see Figure 2. The energy used to pump and to refrigerate the methanol and the biomass burned to supply heat for the reboiler are taken into account in efficiency and carbon utilization analyses.

Hydrogen from the electrolysis process is mixed with the gasifier stream to produce a syngas of hydrogen to carbon monoxide ratio of 2 . This ratio is ideal for many synthetic fuel processes such as the Fischer Tropsch, FT.

The inlet mole composition of the stream at the electrolyzer is $10 \%$ hydrogen and $90 \%$ steam. The heat and electricity provide the energy to split the steam into oxygen and hydrogen. The process out stream is composed of $90 \%$ hydrogen and $10 \%$ steam. The stream is cooled to near ambient temperatures by the Heat Recuperator 1 . The water is separated from the hydrogen at the H2/Water Separator. The water is recycled and mixed with the makeup water. 


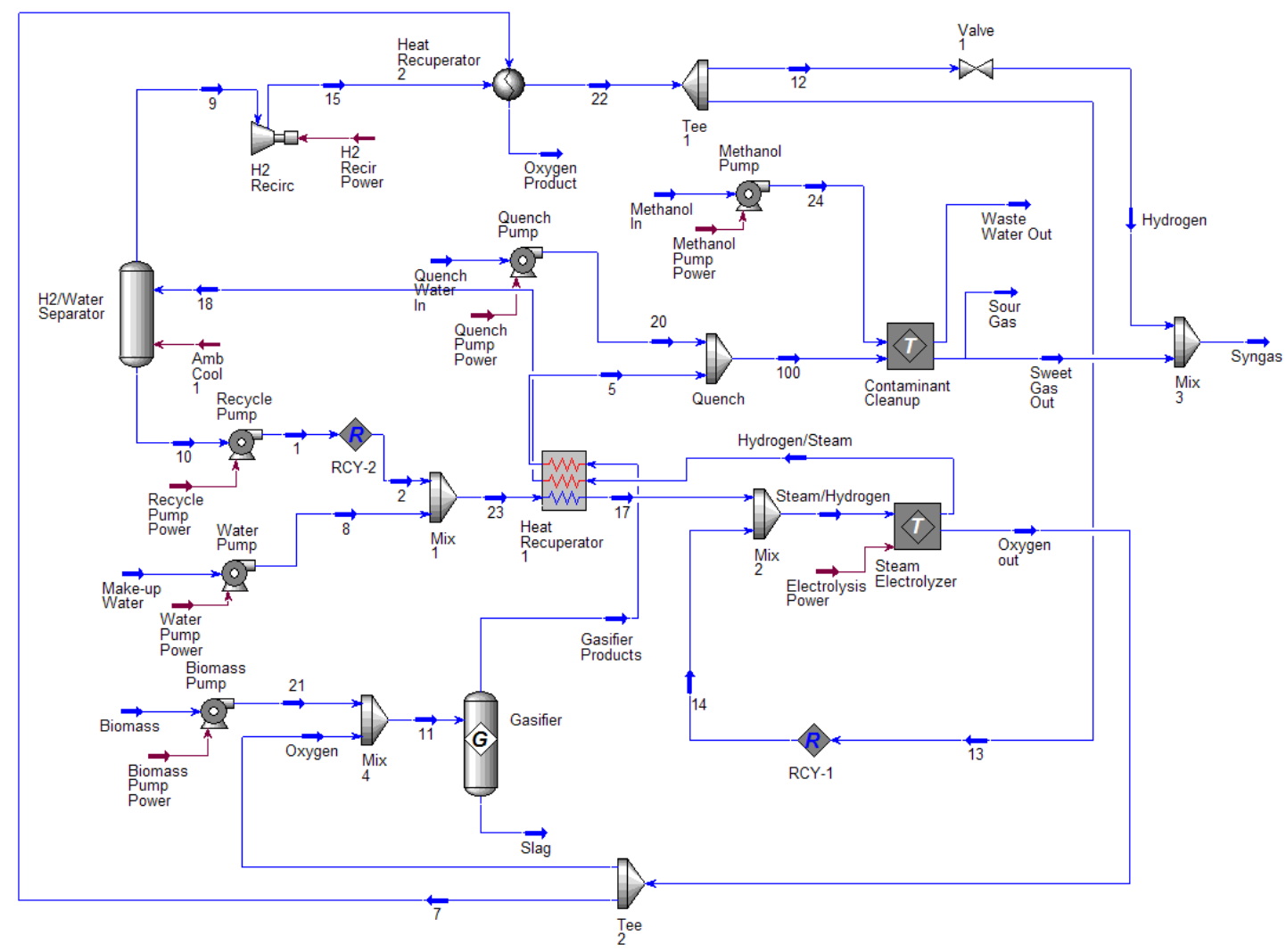

Figure 1. A process flow diagram of biomass gasification with high temperature electrolysis.

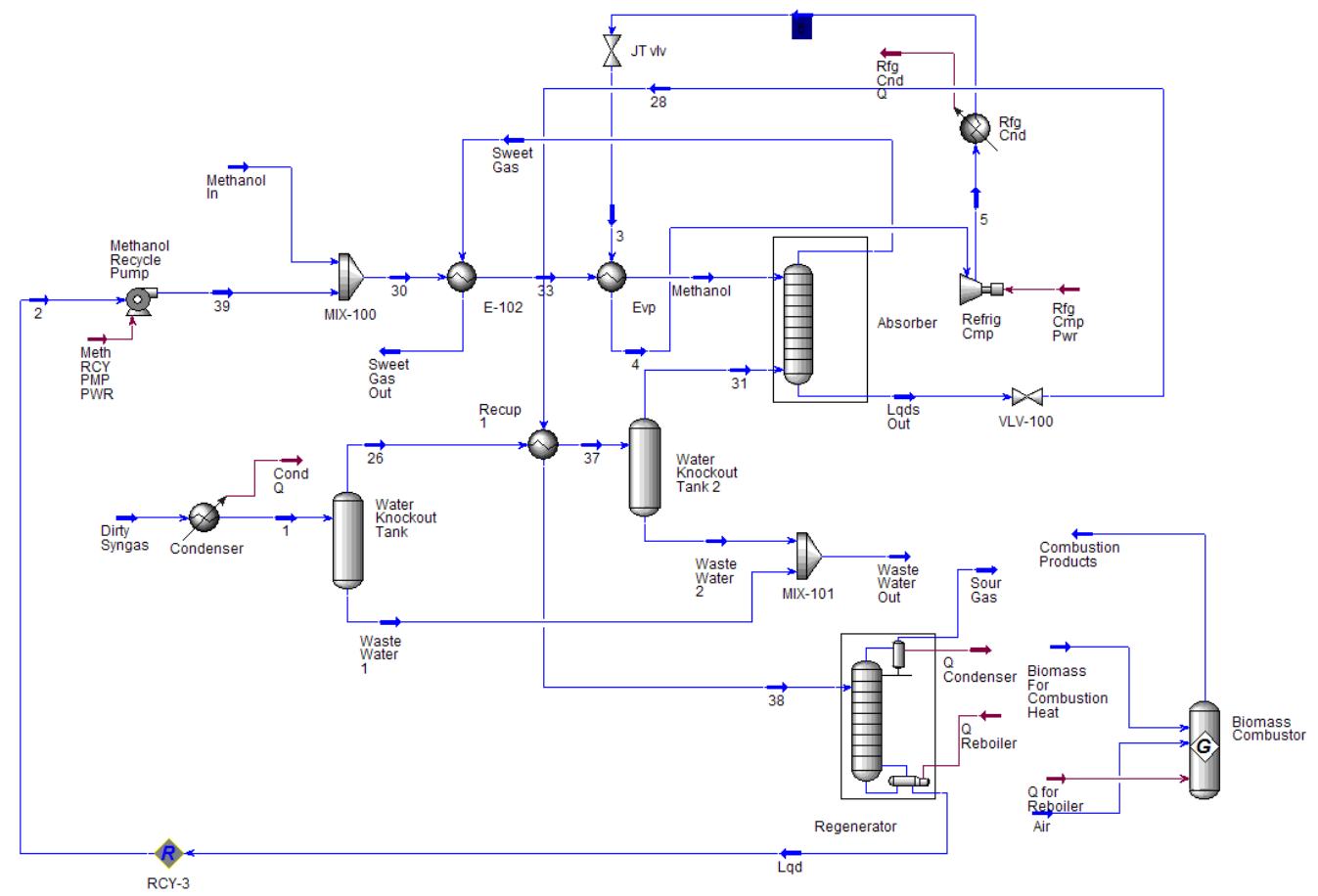

Figure 2. A process flow diagram of the contaminant cleanup process. 
The hydrogen exiting the separator is used primarily for syngas production but some is recycled to the inlet of the electrolysis process to provide reducing conditions at the water side electrode.

Pressure losses in the heat exchangers and the gasifier are set at $20 \mathrm{kPa}$ per pass. An average pressure of $2.78 \mathrm{MPa}$ was assumed for the analysis. The isentropic efficiencies of the pumps and hydrogen circulating compressor are set at $75 \%$. The refrigeration compressor has an efficiency of $90 \%$.

The steam electrolyzer is a module developed at the Idaho National Laboratory to simulate the temperature and compositional averaged Nernst potential of an electrolysis process. Details of the module are found in references $[7,8]$. Given the number of cells, the area specific resistance (ASR), the current density, the cell area, and the inlet flow conditions of the process stream, the module will calculate the average Nernst potential, the per-cell operating voltage, the electrolysis power, the process heat needed and the outlet flow conditions of the hydrogen and oxygen streams. For this run, it was assumed that the ASR was $0.4 \mathrm{ohms}^{*} \mathrm{~cm}^{2}$, the current density was adjusted to provide thermal neutral conditions (adiabatic and isothermal), and the per-cell area was $225 \mathrm{~cm}^{2}$. The thermal neutral conditions set the per-cell operating voltage at 1.288 Volts/cell. The number of cells was adjusted until the hydrogen to carbon monoxide syngas ratio was 2.0. Within the module, a setting was made so that $88.9 \%$ of the steam entering the electrolyzer was converted to oxygen and hydrogen resulting in an outlet stream molar composition of $90 \%$ hydrogen and $10 \%$ steam.

\section{SYNGAS PRODUCTION EFFICIENCY AND CARBON UTILIZATION}

Two measurements of process performance were used in this analysis: the syngas production efficiency and carbon utilization. The syngas production efficiency is defined as the thermal value of the syngas divided by the sum of thermal value of the biomass and the thermal equivalent value of the electricity used in the process. The thermal values of the syngas and the biomass are calculated by multiplying the lower heating values of each with their respective molar flow rates. The thermal value of the electricity is found by summing the electric power of the system and dividing it by the thermal efficiency of the electric power cycle providing the electricity. The heat for the gasification process is not included in this efficiency because the process is adiabatic. The molar flow rate of the biomass is the biomass entering the gasifier and the biomass that is combusted to provide heat for reboiler in the methanol regeneration column. The refrigerator compressor power and the methanol recycle pump power are also included in this efficiency.

$$
\eta_{\text {syngas }}=\frac{\dot{\mathrm{n}}_{\text {syngas }} \mathrm{LHV}_{\text {syngas }}}{\left(\dot{\mathrm{n}}_{\text {biomass }} \mathrm{LHV}_{\text {biomass }}+\sum \mathrm{Pwr}_{\text {elec }} / \eta_{\text {th }}\right)}
$$

The carbon utilization is the mass flow of carbon in the syngas divided by the mass flow of carbon in the biomass. Only the carbon in the carbon monoxide component of the syngas is considered because all components except for hydrogen and carbon monoxide are considered contaminants or inerts.

\section{RESULTS}

A baseline case is outlined to show the process progression. For this case, the gasifier temperature was set at $1500 \mathrm{~K}$. The composition, pressures, temperatures, and flows of the streams into and out of the process are shown in Table 3. The composition is in \% mole fraction unless otherwise indicated. The contaminants and inerts in the syngas are less than $2 \%$ of the total mole faction. However the hydrogen chloride and hydrogen sulfide contents are high enough that they need to be removed. The mixing temperature of the hydrogen and the sweet gas out streams is $426 \mathrm{~K}$ which is low enough that the gas shift reaction need not be considered. The syngas is delivered at a pressure of $2.71 \mathrm{MPa}$ and $426 \mathrm{~K}$ at a hydrogen to carbon dioxide ratio of 2.0. A Fischer Tropsch syngas to synfuel process with a cobalt catalyst needs a syngas feed stream with a ratio of 2.12, pressure at $2.70 \mathrm{MPa}$ and a temperature of $505 \mathrm{~K}[9,10]$. Therefore the syngas will need to be heated before entering a FT process.

For the baseline case, the number of cells in the electrolyzer is 53,000. The current density is 0.6193 amperes per $\mathrm{cm}^{2}$, resulting in a current of 139 amperes. The electrolysis power is $9,500 \mathrm{~kW}$.

The temperature vs. heat flow profiles of the recuperative heat exchangers are shown in Figures 3 and 4. Figure 3 is the Heat Recuperator 1 heat exchanger. The minimum approach is $50{ }^{\circ} \mathrm{C}$ and has a log mean temperature difference, LMTD, of $201{ }^{\circ} \mathrm{C}$. One can see the steam generation in the cold profile. Figure 4 shows the profile for the Heat Recuperator 2 heat exchanger. This heat exchanger also had a minimum approach of $50{ }^{\circ} \mathrm{C}$. The LMTD is $195{ }^{\circ} \mathrm{C}$ for this heat exchanger.

The carbon utilization was calculated to be $94.5 \%$ for this analysis. In other words $94.5 \%$ of the carbon in the biomass was converted to syngas. As stated before this carbon utilized is the carbon found only in the carbon monoxide.

A plot of the syngas production efficiency as a function of the thermal efficiency of the power cycle is found in Figure 5. A power cycle range from $25 \%$ to $55 \%$ was used to include most of the electric power cycles developed. The syngas production efficiency is closely related to the power cycle efficiency. A very high temperature gas GEN IV nuclear reactor has a thermal power cycle efficiency near $50 \%$. If the reactor were used to generate the electricity for the HTE process, the overall syngas efficiency would be near $73 \%$.

A parametric study was performed in which the gasifier temperature was varied between $1500 \mathrm{~K}$ to $1900 \mathrm{~K}$. The 
syngas production efficiency and the carbon utilization are plotted as a function of the gasifier temperature, see Figure 6. The carbon utilization varies slightly with temperature from $94 \%$ to $95 \%$. The syngas production efficiency has a greater dependency on gasifier temperature. As the temperature increases, the syngas production efficiency decreases. More biomass is combusted in the gasifier to provide higher gasifier temperatures, resulting in a composition shift of hydrogen to water and carbon monoxide to carbon dioxide see Figure 7. The carbon shift is slight, but the hydrogen shift is larger, resulting in a need for more hydrogen from the electrolysis process to maintain the correct hydrogen to carbon monoxide ratio of the syngas. Therefore more electrical power is needed to produce the hydrogen causing the syngas production efficiency to decrease.

\section{CONCLUSIONS}

A process model was developed to simulate the generation of syngas by gasification of biomass and high temperature electrolysis of steam. The carbon utilization is affected only slightly by gasifier temperature. The utilization varies between $94 \%$ and $95 \%$. The syngas production efficiency is closely tied to the power cycle efficiency. At a power cycle efficiency of $50 \%$, the syngas production efficiency varies from $70 \%$ to $73 \%$.
Although the analysis looks promising, other biomass inputs would change the configuration. If large concentrations of sodium, potassium or phosphorus compounds are found in the ash, the gasifier temperatures would need to be much lower to prevent slagging.

\section{ACKNOWLEDGMENTS}

This work was supported by the Idaho National Laboratory, Laboratory Directed Research and Development program and by the U.S. Department of Energy, Office of Nuclear Energy, Nuclear Hydrogen Initiative Program.

\section{COPYRIGHT STATEMENT}

This manuscript has been authored by Battelle Energy Alliance, LLC under Contract No. DE-AC07-05ID14517 with the U.S. Department of Energy. The United States Government retains and the publisher, by accepting the article for publication, acknowledges that the United States Government retains a nonexclusive, paid-up, irrevocable, world-wide license to publish or reproduce the published form of this manuscript, or allow others to do so, for United States Government purposes.

Table 3. Composition and flow conditions of the inlet and outlet streams.

\begin{tabular}{|c|c|c|c|c|c|c|c|}
\hline \multicolumn{8}{|c|}{ Molar Composition } \\
\hline & $\begin{array}{l}\text { Biomass } \\
\text { (Mass } \\
\text { Fraction) }\end{array}$ & $\begin{array}{l}\text { Make-up } \\
\text { Water }\end{array}$ & Syngas & $\begin{array}{l}\text { Sour } \\
\text { Gas }\end{array}$ & $\begin{array}{l}\text { Waste } \\
\text { Water }\end{array}$ & $\begin{array}{l}\text { Sweet } \\
\text { Gas Out }\end{array}$ & Hydrogen \\
\hline Hydrogen & & & $65.96 \%$ & $6.44 \%$ & $28 \mathrm{ppm}$ & $45.12 \%$ & $99.90 \%$ \\
\hline Carbon Monoxide & & & $32.98 \%$ & $17.56 \%$ & $36 \mathrm{ppm}$ & $53.23 \%$ & \\
\hline Water & $11.5 \%$ & $100 \%$ & $0.04 \%$ & & $99.97 \%$ & & $0.10 \%$ \\
\hline Carbon Dioxide & & & $0.33 \%$ & $66.07 \%$ & $88 \mathrm{ppm}$ & $0.56 \%$ & \\
\hline Oxygen & & & & $100 \%$ & & & \\
\hline Nitrogen & & & $0.13 \%$ & $0.24 \%$ & $1 \mathrm{ppm}$ & $0.20 \%$ & \\
\hline $\begin{array}{l}\text { Hydrogen } \\
\text { Chloride }\end{array}$ & & & $744 \mathrm{ppm}$ & $6.16 \%$ & $12 \mathrm{ppm}$ & $0.12 \%$ & \\
\hline Hydrogen Sulfide & & & $114 \mathrm{ppm}$ & $0.93 \%$ & $7 \mathrm{ppm}$ & $184 \mathrm{ppm}$ & \\
\hline Methane & & & $0.46 \%$ & $2.59 \%$ & & $0.74 \%$ & \\
\hline Ammonia & & & $4 \mathrm{ppm}$ & $31 \mathrm{ppm}$ & $167 \mathrm{ppm}$ & $7 \mathrm{ppm}$ & \\
\hline Carbonoxysulfide & & & & $6 \mathrm{ppm}$ & & $1 \mathrm{ppm}$ & \\
\hline Barley Straw & $83.6 \%$ & & & & & & \\
\hline Ash & $4.9 \%$ & & & & & & \\
\hline \multicolumn{8}{|c|}{ Flow Conditions } \\
\hline Pressure (MPa) & 0.1013 & 0.1013 & 2.71 & 0.131 & 2.7 & 2.71 & 2.71 \\
\hline Temperature (K) & 289 & 289 & 426 & 185 & 323 & 319 & 606 \\
\hline Mass Flow (kg/s) & 1 & 0.690 & 1.095 & .0166 & 0.117 & 1.017 & 0.078 \\
\hline
\end{tabular}




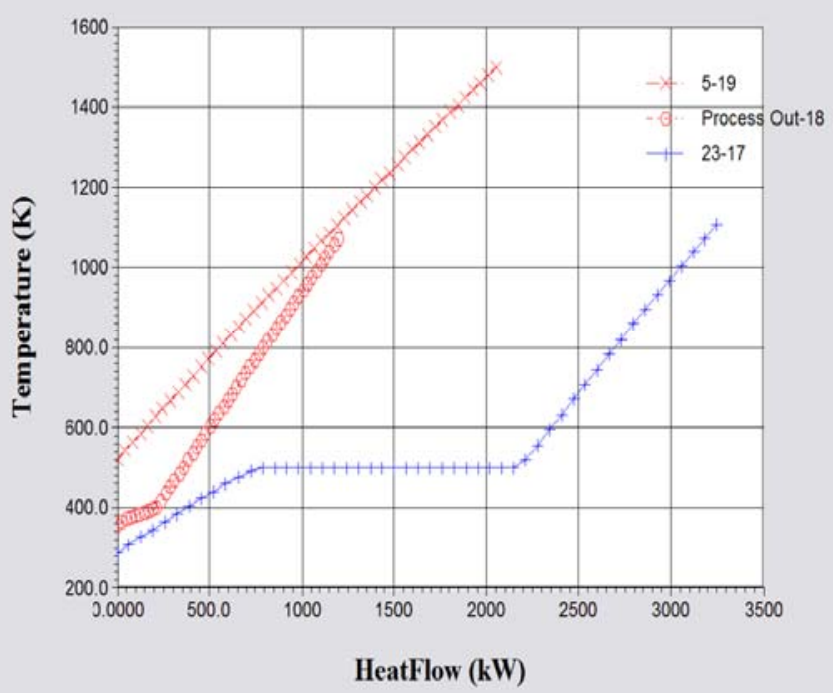

Figure 3. Temperature profile plot for the Heat Recuperator 1 heat exchanger.

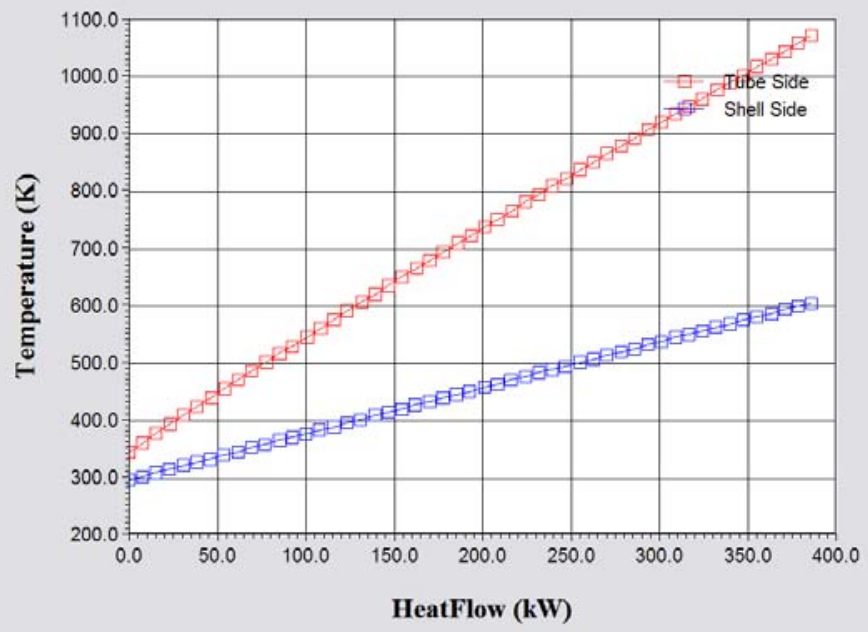

Figure 4. Temperature profile plot for the Heat Recuperator 2 heat exchanger.

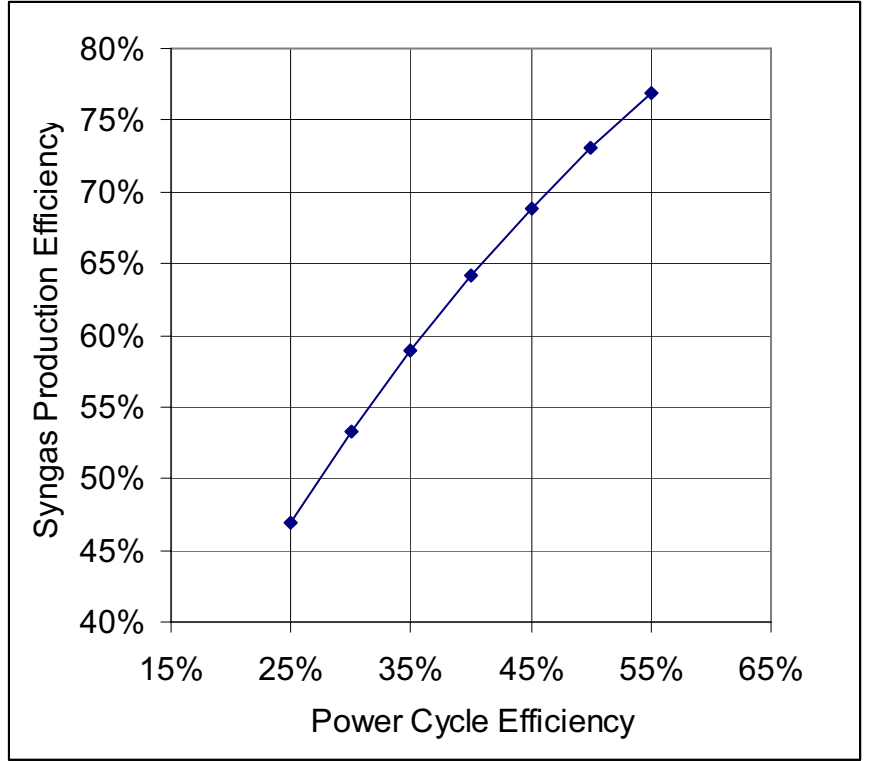

Figure 5. Syngas Production Efficiency as a function of the thermal efficiency of the power cycle.

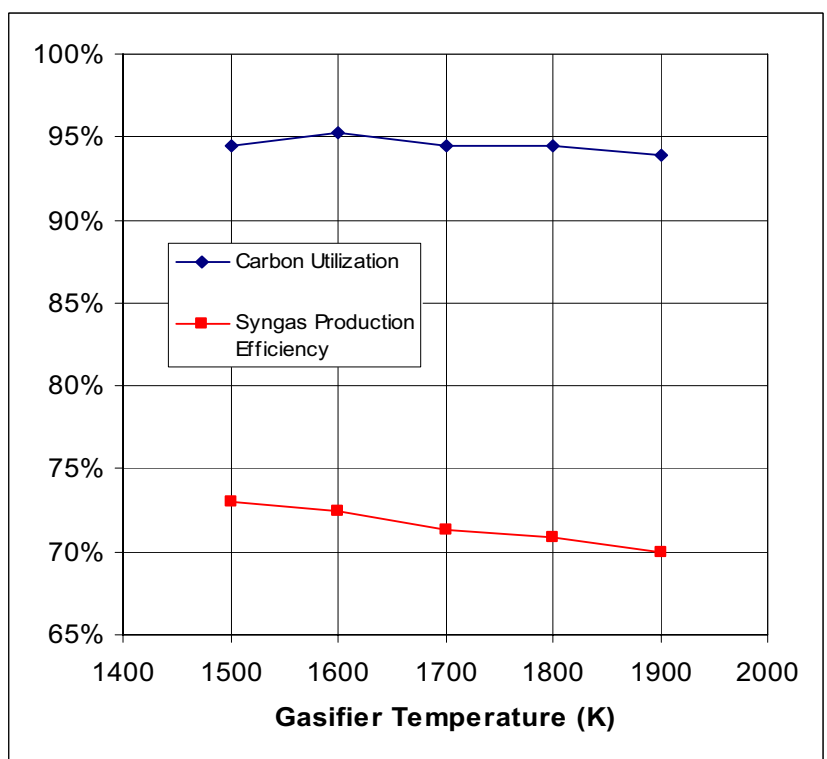

Figure 6. Carbon utilization and syngas production efficiency as a function of the gasifier temperature. 


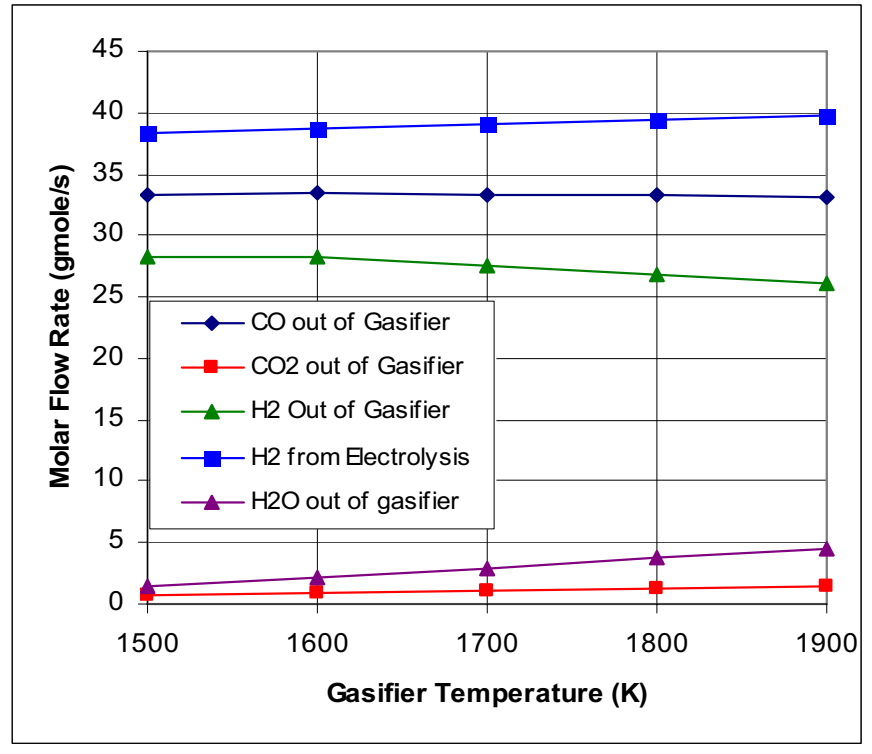

Figure 7. Molar flow rates of $\mathrm{CO}, \mathrm{CO} 2$, water, and hydrogen out of gasifier and electrolysis process.

\section{REFERENCES}

1. Higman, Christopher, and Maarten van der Burgt, 2003, Gasification, San Diego; Elsevier, pp. 72-75.

2. 2001, Kirk-Othmer Encyclopedia of Chemical Technology, Topic: Hydrogen, New York: John Wiley \& Sons, Inc., Vol. 13, pp. 776-777

3. Probstein, R. F., R. E. Hicks, Synthetic Fuels, Dover Publications, Inc. Mineola, New York, 2006.

4. UniSim Design, R360 Build 5, Honeywell International Inc., Copyright 2005-2006.

5. PHYLLIS, ECN-Biomass, Version 4.13, Energy Research Centre of the Netherlands (ECN), www.ecn.nl/phyllis.

6. Suidevel, P. L., "Shell Coal Gasification Process for Power and Hydrogen/Chemicals." GTC Conference, Washington D.C., October 2004.

7. O'Brien, J. E., McKellar, M. G., Hawkes, G. L., and Stoots, C. M., "Development of a One-Dimensional CoElectrolysis Model for Use in Large-Scale Process Modeling Analysis," Fifth International Conference on Fuel Cell Science, Engineering \& Technology, June 1820, 2007, New York, USA.

8. O’Brien, J. E., McKellar, M. G., Stoots, C. M., Herring, J. S., and Hawkes, G. L., "Parametric Study of Large-Scale Production of Syngas via High Temperature Electrolysis," in review, International Journal of Hydrogen Energy, 2008.

9. Dry, Mark E., "High Quality Diesel via the FischerTropsch Process -- A Review," 2002, Journal of Chemical Technology and Biotechnology, Vol. 77, No. 1, pp. 43-50.

10. Steynberg, A. P., and Dry, M. E., 2004, Studies in
Surface Science and Catalysis, 152, Fischer-Tropsch Technology, San Diego: Elsevier, pp. 196-257 